\title{
The presence of hyperostosis in Atlantic moonfish, Selene setapinnis (Mitchill, 1815) in the Brazilian Coast - case report
}

[A presença de hiperostoses no peixe-galo-sem-penacho, Selene setapinnis (Mitchill, 1815) na costa brasileira - relato de caso]

\author{
F.A.P. Tuna ${ }^{1,2}$, F.A.A. Calixto ${ }^{1,3}$, M.C. Salomão ${ }^{4}$, C.E.R. Coutinho ${ }^{1}$, \\ K.R. Estanek ${ }^{4}$, E.F.M. Mesquita ${ }^{4}$
}

${ }^{1}$ Fundação Instituto de Pescado Estado do Rio de Janeiro - Niterói, RJ

${ }^{2}$ Aluno de pós-graduação - Universidade Federal Fluminense - Niterói, RJ

${ }^{3}$ Cenro Universitário Serra dos Órgãos - Teresópolis, RJ

${ }^{4}$ Universidade Federal Fluminense - Niterói, RJ

\begin{abstract}
The occurrence of hyperostotic bones is common in marine fish, especially in the Carangidae family, despite few records of this condition in fishes from Brazilian waters. The present study describes the occurrence of hyperostosis in Atlantic moonfish (Selene setapinnis) in, Rio de Janeiro State, Brazil. Radiographs of the fish specimens were taken and all of them presented hyperostosis in at least three different regions: cleithrum, pterygiophores and pleural ribs. The observed pattern is different from previously described for other species of the same genus. It is the first record for the species and a valuable contribution to the study of bone diseases in fishes from the Brazilian coast.
\end{abstract}

Keywords: Carangidae, marine fishes, bone diseases

\section{RESUMO}

A ocorrência de ossos hipertostóticos é comum em peixes marinhos, especialmente na família Carangidae, apesar de poucos relatos dessa condição em peixes de águas brasileiras. O presente estudo descreve a ocorrência de hiperostose no peixe-galo-sem-penacho (Selene setapinnis) no estado do Rio de Janeiro, Brasil. Radiografias dos espécimes de peixes foram feitas e todos os exemplares apresentaram hiperostoses em pelo menos três regiões diferentes: cleithrum, pterigióforos e costelas pleurais. O padrão observado é diferente do descrito previamente para outras espécies do mesmo gênero. Este é o primeiro relato para a espécie e é uma contribuição valiosa para o estudo de doenças ósseas em peixes da costa brasileira.

Palavras-chave: Carangidae, peixes marinhos, doenças ósseas

\section{INTRODUCTION}

The increase of periosteal osteogenesis that modifies normal bone morphology is defined as hyperostosis (Meunier et al., 2010). This condition causes bone thickening and swollen shape (Olsen, 1971; Desse et al., 1981; Meunier and Desse, 1986; Gauldie and Czochanska, 1990; Smith-Vaniz et al., 1995). Several families of marine teleost fishes are often described with the condition, although the etiology and implications remain unclear. Different hypothesis about this disorder have been proposed.

Schlüter et al. (1992) suggested the presence of hyperostotic bones as a physiological response to chemically adverse environment. Gauldie and Czochanska (1990) described it as a possible genetic control. Lima et al. (2002) reported the high incidence of hyperostosis in individuals of cutlass fish Trichiurus lepturus (Linnaeus, 1758) as osteoma, a usual type of tumor described in fishes. Many authors considered hyperostosis as

Recebido em 3 de agosto de 2020

Aceito em 5 de novembro de 2020

E-mail: tunafernando@gmail.com 
non-pathological condition (Desse et al., 1981; Gauldie and Czochanska, 1990.; Smith-vaniz et al., 1995).

Hyperostotic bones is often observed in speciesspecific structures like haemal and neural spines, ribs, pterygiophores (Desse et al., 1981), despite of taxonomically related species can exhibit different patterns for hyperostosis (Smith-Vaniz et al., 1995). Tuna (2015) showed that the same individual can develop several affected regions simultaneously. Although the occurrence of hyperostosis apparently does not affect the consumption, it leads to a possible bacterial contamination and makes filleting difficult, causing loss of muscle tissue and imperfections in the cut (Giarratana et al., 2012; Ramos and Faisca., 2016) which can make filleting process impossible at industrial level (Lima et al., 2002). Smith-Vaniz et al (1995) describe the presence of this condition in 92 species divided into 22 families.

Even though a clear taxonomic pattern does not seem to exist, some studies demonstrate a high prevalence of hyperostosis in individuals from the Carangidae family (Smith-Vaniz et al., 1995; Béarez, 1997; Chanet, 2018), a family with several species of commercial importance in the southeast-south of the Brazilian coast (Report..., 2018). The present study reports the occurrence of hyperostosis in specimens of Selene setapinnis (Mitchill, 1815). This is the first case reported for hyperostosis in this species and one of the few cases reported in Brazilian waters.

\section{MATERIALS AND METHODS}

Nine specimens of Atlantic moonfish were acquired in the Cabo Frio region, Rio de Janeiro, Brazil. The specimens were identified, sexed and biometrics were performed for total length, standard length, and total weight. X-ray radiography was conducted using the X-ray equipment MAG 300mA, performed in collimator calibrated $50 \mathrm{Kv} / 160 \mathrm{~mA}$ in radiographic cassettes of $35 \times 43$ and $24 \times 30 \mathrm{~cm}$. The radiographic images were processed using the software Sante Dicom Viewer Pro.

\section{RESULTS}

The mean and standard deviation for the total length of the fishes were $38.8 \mathrm{~cm} \pm 1.28 \mathrm{~cm}$ (ranged from 36.5 to $40.5 \mathrm{~cm})$. The standard length averaged was $29.1 \mathrm{~cm} \pm 1.58 \mathrm{~cm}$ (ranged from 25.7 to $30.7 \mathrm{~cm}$ ). The average weight was $690.4 \mathrm{~g}$, with standard deviation \pm 64 .2grams (ranged from 614 to $783 \mathrm{~g}$ ). All specimens analyzed had skeletal deformities, varying in number and type of affected structures.

Hyperostosis was found in pterygiophores of all analyzed specimens. The number of pterygiophores affected ranged from 15 to 23 . The presence of this condition on both sides of the cleithrum was also observed in almost all individuals, except for one male specimen. Seven individuals had deformations in the first pair of ribs. Hyperostosis in the supraoccipital, haemal spines, neural spines or other bones were absent (Figure 1).

\section{DISCUSSION}

Only three structures were affected: cleithrum, ribs and pterygiophores. After the analysis of radiographic images, it was determined that with the pterygiophores the most affected structures considering the thickening and amount of bones (Figure 2). Male and female specimens had their bones affected, corroborating with previous studies that reported the development of condition in both genders (Lima et al.; 2002; Paig-Tran et $a l . ; 2016)$.

The observed pattern for $S$. setapinnis in the present work was different from the described in previous studies for other species of the same genus. Béarez (1997) reported the presence of condition in the supraoccipital region in skeletons of individuals from $S$. brevoorti (Gill, 1863) and $S$. peruviana (Guichenot, 1866) found in archaeological sites in Ecuador. Guzman and Polaco (2002) observed the hyperostosis in the cranial region, cleithrum and neural spines in three individuals of $S$. vomer and S. brevoorti from zooarchaeological collections in Mexico.

Different patterns in related species can be found (Smith-Vaniz et al., 1995; Rapisarda et al., 2008). Trichiurus lepturus (Linnaeus, 1758) collected in different studies (James, 1960; Lima et al., 2002; Al Nahdi et al., 2016) the incidence of individuals with hyperostosis ranged from $94.5 \%$ to $10.5 \%$. These differences in presence versus absence of the condition and patterns could not be analyzed as a single factor. The occurrence of hyperostosis 
related to a genetic factor (Smith-Vaniz et al., 1995; Jawad, 2013) could explain the fact that species living in the same environment may present different prevalence, including the complete absence of condition. Physiological or environmental factors could justify the presence of this bone condition, as an aid to support the fin (erection aid), aging, temperatures, water chemical composition, pathogenic factors, floating aid, hydrostatic maintenance, hypersaline environments, among others (Murty, 1967; Meunier and Desse, 1986; Smith-Vaniz et al., 1995; Gaudant and Meunier, 1996; Chang et al., 2008; Meunier et al., 2008; Giarratana et al., 2012; Paig-Tran et al ., 2016; Chanet, 2018).

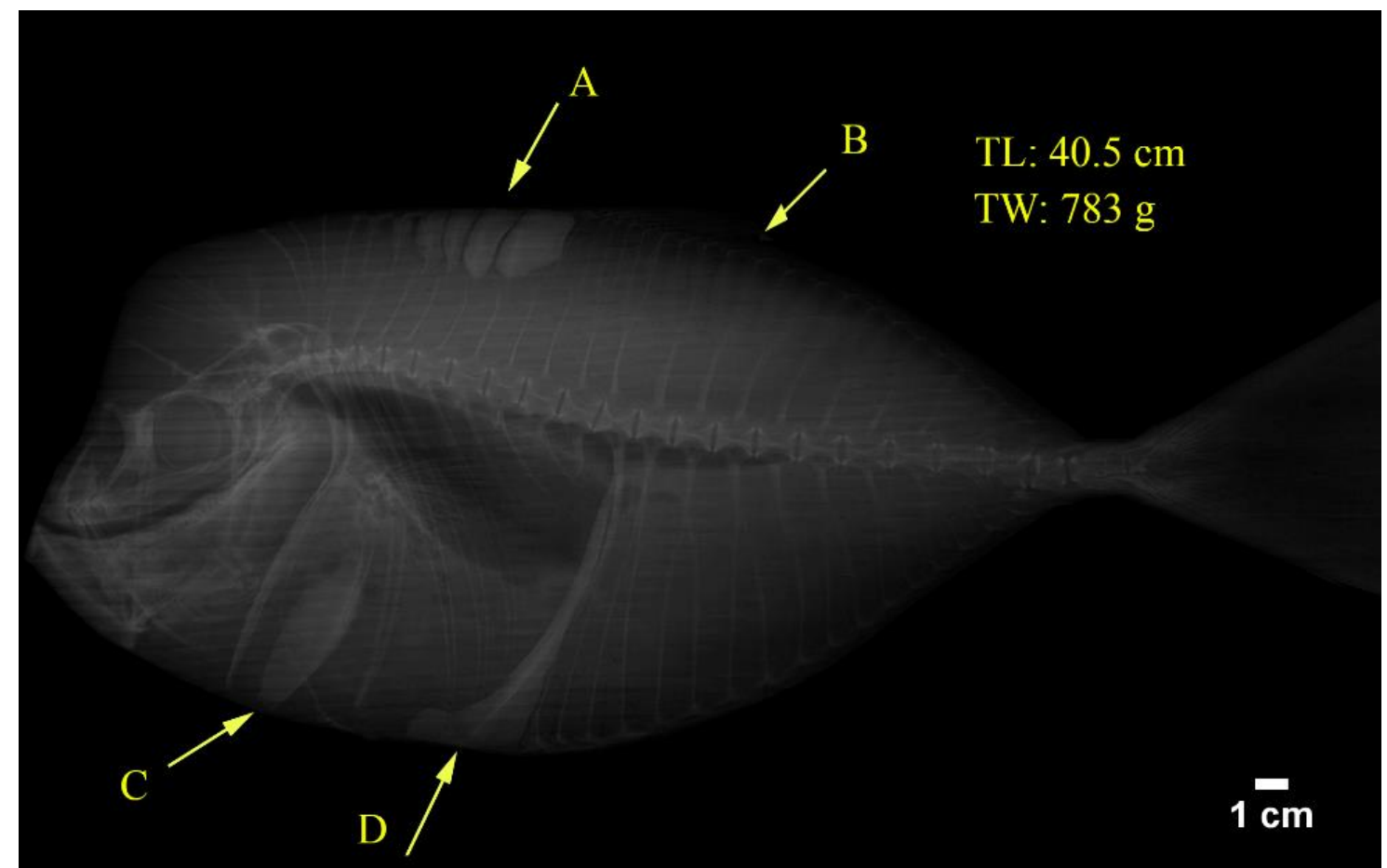

Figure 1. Radiography image of a specimen S. setapinnis, total length $40.5 \mathrm{~cm}$ and total weight $783 \mathrm{grams}$ with the presence of hyperostosis observed in four distinct regions - A and B: Pterygiophores - C: Cleithrum - D: Rib. The condition is more evident in the first series of pterygiophores.

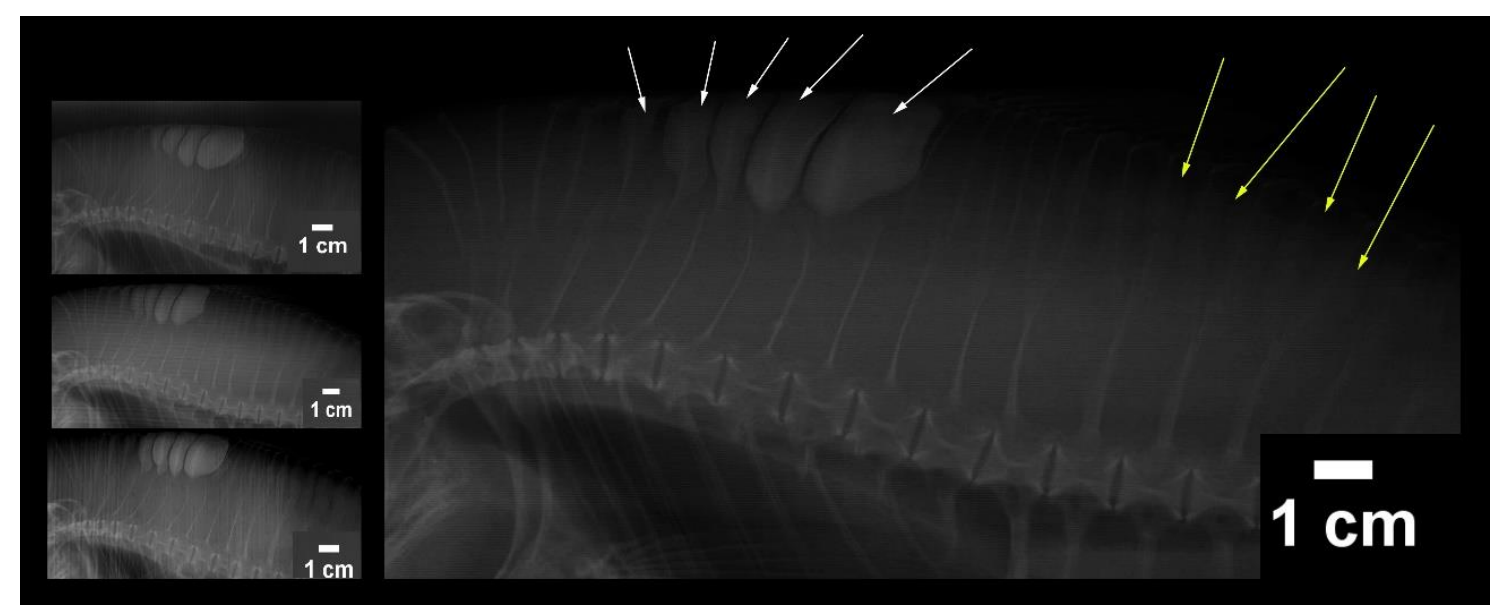

Figure 2. Radiographic images of dorsal view of four samples of Selene setapinnis, total length average $38.8 \mathrm{~cm}$, demonstrating the described pattern. The white arrows indicate the thickened affected pterygiophores and yellow arrows indicate pterygiophores with not evident process. 


\section{CONCLUSIONS}

The present study is the first record of hyperostosis in different individuals of Selene setapinnis from southern-south waters of Brazil. The patterns described for the presence of hyperostosis differ from the affected bones of other species of the same genus. The cause of hyperostosis remains unclear and further research is necessary to elucidate future questions about the epidemiology of this disorder.

\section{ACKNOWLEDGEMENTS}

The authors would like to thank the entire radiographic staff of the veterinary hospital of Federal Fluminense University for the support and the radiographic images produced for the present work.

\section{REFERENCES}

AL NAHDI, A.; DE LEANIZ, C.G.; KING, A.J. Two distinct hyperostosis shapes in ribbonfish, Trichiurus lepturus Linnaeus 1758. Bull. Eur. Assoc. Fish Pathol., v.36, p.132-136, 2016.

BÉAREZ, P. Las piezas esqueléticas diagnósticas en arqueo ictiología del litoral ecuatoriano. Bull. Inst. Fr. Études Andines, v.26, p.11-20, 1997.

CHANET, B. Swollen bones in jacks and relatives (Teleostei: Acanthomorphata: Carangidae). Cybium Int. J. Ichthyol., v.42, p.99-103, 2018.

CHANG, M.; WANG, X.; LIU, H. et al. Extraordinarily thick-boned fish linked to the aridification of the Qaidam Basin (northern Tibetan Plateau). Proc. Nat. Acad. Sci., v.105, p.13246-13251, 2008

DESSE, G.; MEUNIER, F.J.; PERON M.; LAROCHE, J. Hyperostose vertébrale chez l'animal. Rhumatologie, v.33, p.105-119, 1981.

GAUDANT, J.; MEUNIER, F.J. Observation d'un cas de pachyostose chez un Clupeidae fossile du Miocène terminal de l'ouest algérien, Sardina Crassa (Sauvage, 1873). Cybium Int. J. Ichthyol., v.20, p.169-183, 1996.

GAULDIE, R.W.; CZOCHANSKÁ, Z. Hyperostotic bones from the New Zealand snapper, Chrysophrys auratus (Sparidae). Fish. Bull., v.88, p.201-206, 1990.
GIARRATANA, F.; RUOLO, A.; MUSCOLINO, D. et al. Occurrence of hyperostotic pterygiophores in the silver scabbardfish, Lepidopus caudatus (Actinopterygii: Perciformes, Trichiuridae). Acta Ichthyol. Piscatoria, v.42, p.233-237, 2012.

GUZMÁN, A.F.; POLACO, O. Hiperostosis en peces mexicanos. Archaeofauna, v.11, p.45-62, 2002.

JAMES, P. Instances of excessive thickening of certain bones in the ribbon fish, Trichiurus lepturus Linnaeus. J. Mar. Biol. Assoc. India, v.2, p.253-258, 1960.

JAWAD, L.A. Hyperostosis in three fish species collected from the Sea of Oman. Anat. Rec. v.296, p.1145-1147, 2013.

LIMA, F.C.; SOUZA, A.P.M.; MESQUITA, E.F.M.; SOUZA, G.N.; CHINELLI, V.C.J. Osteomas in cutlass fish, Trichiurus lepturus from Niteroi, Rio de Janeiro state, Brazil. J. Fish Dis., v.25, p.57-61, 2002.

MEUNIER, F.J.; DESSE, G. Les hyperostoses chez les téléostéens: description, histologie et problèmes étiologiques. Ichthyophysiol. Acta, v.10, p.130-141, 1986.

MEUNIER, F.J.; DESCHAMPS, M.H.; LECOMTE, F. et al. The skeleton of teleostean fish: Structure, development, physiology, pathology. Bull. Soc. Zool. Fr., v.133, p.9-32, 2008.

MEUNIER, F.J.; GAUDANT, J.; BONELLI, E. Morphological and histological study of the hyperostoses of Lepidopus albyi (Sauvage, 1870), a fossil Trichiurideae from the Tortonian (Upper Miocene) of Piedmont (Italy). Cybium Int. J. Ichthyol., v.34, p.293-301, 2010.

MURTY, V.S. Notes on hyperostosis in the fish Drepane punctata (Linnaeus). J. Mar. Biol. Assoc. India, v.9, p.323-326, 1967.

OLSEN S.J. Swollen bones in the atlantic cutlass fish Trichiurus lepturus Linnaeus. Copeia, v.1, p.174-175, 1971.

PAIG-TRAN, E.M.; BARRIOS, A.S.; FERRY, L.A. Presence of repeating hyperostotic bones in dorsal pterygiophores of the oarfish, Regalecus russellii. J. Anat., v.229, p.560-567, 2016. 
RAMOS, P.; FAISCA, P. Hyperostotic bones in bronze croaker, otolithoides bi-auritus (Cantor, 1849) - importance for the processing industry and consumers. Exp. Pathol. Health Sci., v.8, p.67-68, 2016.

RAPISARDA, G.; MACRÌ, F.; MANGANARO, M. et al. Iperostosi in ricciola (Seriola dumerilii) e pagro (Pagrus pagrus). [Hyperostosis ingreater amberjack (Seriola dumerilii) and common seabream (Pagrus pagrus).] Ittiopatologia, v.5, p.195-200, 2008.

RELATÓRIO técnico semestral 01 PMAPRJ_BR_04033014-18_RTS-01,2018. Rio de Janeiro: FIPERJ PMAP, 2018. Disponível em: http://www.fiperj.rj.gov.br/index.php/publicacao/ index/1. Acessado em: 14 jul. 2020.
SCHLÜTER, T.; KOHRING, R.; MEHL, J Hyperostotic fish bones ('Tilly bones') from presumably Pliocene phosphorites of the Lake Manyara area, Northern Tanzania. Paläontologische, v.66, p.129-136, 1992.

SMITH-VANIZ， W.F.; KAUFMAN， L.S.; GLOVACKI, J. Species-specific patterns of hyperostosis in marine teleost fishes. Mar. Biol., v.121, p.573-580, 1995.

TUNA, F.A.P Comparative characterization of hyperostosis in two different species of family Ephippidae bleeker, 1859. Sky J. Agricult. Res., v.4, p.109-113, 2015. 